\title{
Acute Toxicity and Genotoxic Activity of Leunca (Solanum nigrum L.) Herb Ethanolic Extract
}

\author{
Rumiyati $^{1^{*}}$, Laili Nailul Muna ${ }^{2}$, Devi Nisa Hidayati ${ }^{2}$, Riris Istighfarie Jenie ${ }^{1,2}$ \\ ${ }^{1}$ Faculty of Pharmacy, Universitas Gadjah Mada, Yogyakarta, Indonesia \\ ${ }^{2}$ Cancer Chemoprevention Research Center, Faculty of Pharmacy, Universitas Gadjah Mada, \\ Yogyakarta, Indonesia
}

\begin{abstract}
Previous studies showed that Leunca herb ethanolic extract (LHE) has cytotoxic activity in several cancer cell lines such as HepG2 and HT-29. The extract also demonstrated as potential agent to be developed as co-chemotherapeutic in combination with doxorubicin and cisplatin. The combination is supposed to reduce occurance of cell resistance and toxicity towards normal cell. In order to verify safety before being applied to human, toxicological and genotoxic evaluation of the extract is important to be done. This research was therefore aimed to investigate acute toxicity and genotoxic activity of LHE. The acute toxicity study was carried out in three groups of 5 mice that was orally administrated by LHE at different doses consisting 300, 2000 and $5000 \mathrm{mg} / \mathrm{kgBW}$. Mortality and sign of toxicity were observed during 7 days. Genotoxic activity was carried out using Mononuclear Polychromatic Erythrosite (MNPCE) assay at a doses range of 250, 500, and $1000 \mathrm{mg} / \mathrm{kgBW}$. Cyclophosphamide (CYP) at the dose of $50 \mathrm{mg} / \mathrm{kg}$ was used as positive control. The result showed that LHE did not cause lethal effect on animal model up to doses of $5000 \mathrm{mg} / \mathrm{kgBW}$. However, toxicity signs were found in animal model on day 0-6 of the observation. LHE had lower genotoxic activity compared to cyclophosphamide at the doses of 250, 500, and 1000 $\mathrm{mg} / \mathrm{kg}$. The low genotoxic activity and acute toxicity of LHE suggested that the extract might be safe to be used as medicine.
\end{abstract}

Keyword: leunca herb ethanolic extract, genotoxicity, acute toxicity

\section{INTRODUCTION}

Leunca (Solanum nigrum L.) herb is used in Indonesian community as lalapan that is served as uncooked vegetable and eaten together with rice. Previous studies demonstrated that Leunca herb extract is potential to be developed as a chemopreventive agent due to its activity on some cancer cell lines, such as MCF-7, T47D, and HeLa cells. The extract could enhance cytotoxic effects of doxorubicin on MCF-7 and T47D breast cancer cells and also could increase cytotoxic effects of cisplatin on HeLa cervical cancer cells (Princess, et al., 2010; Anindyajati, et al., 2010, and Istiaji, et al., 2010). Solanine and solamargine are known as main active compounds that have cytotoxic activity. The cytotoxic activity has been reported by mechanism of inhibition of cell cycle on G2/M phase arrest and by apoptosis induction through a reduction in $\mathrm{Bcl}-2$ expression ( $\mathrm{Ji}$, et al., 2008).

One of chemotherapy agents commonly used in therapy of breast cancer is doxorubicin. However, long-term doxorubicin therapy can induce cell resistance which is characterized by induction of high level P-glycoprotein (Pgp) expression in the cells. The overexpression of Pgp can cause efflux of chemotherapeutic agents in cells, lowering the effects of the therapy. Therefore, development of a therapeutic agents that can decrease Pgp expression in cancer cells is important to be done in order to overcome occurence of resistance in breast cancer therapy.

*Corresponding author e-mail: rumiyaris@ugm.ac.id 
One of the parameter for a compound's genotoxicity is through the observation of micronuleus (Krishna, et al., 2000). Micronucleus is a manifestation of the mutation. As the the chromosome breaks, it is shown as micro-sized nucleus in the cell.

Micronucleus is easy to find in the polychromatic erythrocytes. The number of micronucleus polychromatic erythrocyte would show the genetic damage in the erythropoetic system in organism. One of the compound that could evoke MNPCE formation is cyclophosphamide. Cyclophosphamide is widely used in the treatment of leukemia, lymphoblastoma, ovarian cancer, and breast cancer. Cyclophosphamide would be active as a cancer drug if it has been metabolized by the liver first (Anderson, et al., 1995). Then, the acute toxicity test was done to determine the toxic effect that happend in a short periode that is 24 hours after exposure of a single dose compound.

This study was aimed to determine the safety of the tested compound. The purposes of acute toxicity testing are to obtain information on the biologic activity of a chemical and gain insight of its mechanism of action. The information of acute systemic toxicity generated by the test is used in hazard identification and risk management in the context of production, handling, and use of chemicals. The $\mathrm{LD}_{50}$ value is defined as the statistically derived dose that, when administered in an acute toxicity test, is expected to cause death in $50 \%$ of the treated animals in a given period (Walum, 1998).

\section{MATERIALS AND METHOD}

\section{Leunca Ethanolic Extract}

Leunca (Solanum nigrum L.) herb was obtained from Balai Besar Penelitian dan Pengembangan Tanaman Obat dan Obat Tradisional, Tawangmangu, Solo, Central Java, Indonesia. As many as $3 \mathrm{~kg}$ of leunca powder was macerated with $70 \%$ ethanol for 5 days. The extract was concentrated by rotary vacuum evaporator.

\section{In Vivo Antigenotoxicity Assay}

As many as 35 Balb-c mice aged 6-7 weeks and weighed 22.5-27.5 g were divided into 7 groups, each consisting 5 mice per group. Each group was placed in plastic boxes with the temperature of $23-25^{\circ} \mathrm{C}$ and $70-80 \%$ humidity. The animals were given pellet as meal and water ad libitum. The treatment of LHE was done for 7 days. Then, the treatment of CYP was given with the dose of $50 \mathrm{mg} / \mathrm{kgBW}$ for two times in the last two days of treatment. In the last day of treatment, peripheral blood smear were made on microscope slides, continued by methanol fixation for 15 minutes, and Giemsa staining (10\% in Phosphate Buffer Saline (PBS) pH 6.8) for an hour. The slides were observed using microscope (Olympus) with 1000x magnification. The numbers of MNPCE per 1000 Polychromatic Erythrocytes (PCE) were counted. In order to avoid the negative false results and to know the toxicity of the substances administered, the ratio of PCE and Normochromatic Erythrocytes (NCE) were counted per $2000 \mathrm{NCE}+\mathrm{PCE}$ cells. One way Anova and Tukey Significancy test $(p<0.05)$ statistical analysis were done by using SPSS 16.0 .

\section{In Vivo Accute Toxicity Assay}

As many as 42 Balb-c mice eight weeks aged and 190-210 g weighed were divided into 7 groups. One group was used as control, and another five groups were the treated groups. Single dose treatment with various dose of LHE were given started from the lowest considered as the safe dose until the highest dose which could make the toxic condition for tested animals. Observation of toxicity symptoms, manifestation, and mechanism was done for 24 hours.

\section{RESULT AND DISCUSSION}

\section{The Result of Acute Toxicity Assay}

The treatment of LHE in the dose of 300 , 2000 , and $5000 \mathrm{mg} / \mathrm{kgBW}$ showed the toxic symptom as shown in Balazs (1970) table in the initial hours until six hours later (Table 3). 
The toxic symptom was not showed eight hours until seven days later.

According to the observation, toxic symptoms of LHE appeared in the initial hours until six hours later, but the toxic symptoms did not appear after the eighth hour until seven days later. No death observed because leunca ethanolic extract did not affect performance of the vital organs. The observation was done macroscopically which showed the toxic symptom.

The toxic condition is including the death of animal tested which was used to decide the potential of acute toxicity (LD50) of LHE. This observation showed that the treatment of LHE in the highest dos (1000 mg/kgBW), didn't cause the death of the animal groups. It means that LHE is not toxic at the treatment doses. Therefore, the LD50 could not be determined in this study.

\section{The Result of In Vivo Antigenotoxicity Assay}

The antigenotoxic effect of LHE can be determined by the parameter of MNPCE/1000 $\mathrm{PCE}$ and PCE/PCE+NCE ratio per 2000 cells. Based on this study, the doses of 250; 500; and $1000 \mathrm{mg} / \mathrm{kgBW}$ LHE could reduce the number of MNPCE/1000 PCE compared to the CYP control group (Table 1). This ressult showed the effect of LHE in the inhibition of genetis damage in the erythropoietic system induced by CYP. Besides that, LHE could also increase the parameter of $\mathrm{PCE} / \mathrm{PCE}+\mathrm{NCE}$ ratio per 2000 cells compared to the CYP control group (Table II). It showed that LHE didn't cause DNA toxicity.

Table I. Balazs table (Balazs T., 1970)

\begin{tabular}{|c|c|c|}
\hline Organ system & $\begin{array}{l}\text { Observatioun and } \\
\text { examination }\end{array}$ & Common signs of toxicity \\
\hline \multirow{3}{*}{$\begin{array}{l}\text { CNS and } \\
\text { somatomotor }\end{array}$} & behaviour & $\begin{array}{l}\text { unusual aggressiveness, unusual vocalization, restlessness, } \\
\text { sedation. }\end{array}$ \\
\hline & movements & twitch, tremor, ataxia, catatoni, paralysis, convulsion \\
\hline & $\begin{array}{l}\text { reactivity to various } \\
\text { stimuli }\end{array}$ & irritability, passivity, anesthesia, hyperesthesia \\
\hline Respiratory & character and rate & Bradypnoea, dyspnoea, \\
\hline Cardiovascular & $\begin{array}{l}\text { palpation of cardiac } \\
\text { region }\end{array}$ & Bradycardia, arrhythmia \\
\hline \multirow{2}{*}{ Gastrointestinal } & events & Diarrhea, constipation \\
\hline & feces consistency & unformed \\
\hline Skin and fur & color, turgor, intergrity & piloerection, reddening, eruptions \\
\hline Other & general condition & abnormal posture, emaciation \\
\hline
\end{tabular}


Table 2. The antigenotoxic effect as the parameter of MNPCE/I000 PCE

\begin{tabular}{|c|c|c|c|c|c|}
\hline \multirow[b]{2}{*}{ Groups } & \multicolumn{5}{|c|}{ MNPCE / I000 PCE } \\
\hline & $\begin{array}{c}\text { Replication } \\
\text { I }\end{array}$ & $\begin{array}{c}\text { Replication } \\
2\end{array}$ & $\begin{array}{c}\text { Replication } \\
3\end{array}$ & $\begin{array}{c}\text { Replication } \\
4\end{array}$ & Average \\
\hline Negative control & 8 & 6 & 10 & 10 & 8.5 \\
\hline CYP control & 33 & 39 & 37 & 40 & 37.25 \\
\hline $1000 \mathrm{mg} / \mathrm{kgBW}$ of LHE control & 5 & 4 & 6 & 3 & 4.5 \\
\hline Solvent control & 7 & 7 & 8 & 12 & 8.5 \\
\hline $250 \mathrm{mg} / \mathrm{kgBW}$ of LHE + CYP & 21 & 26 & 28 & 25 & 25 \\
\hline $500 \mathrm{mg} / \mathrm{kgBW}$ of LHE + CYP & 14 & 17 & 11 & 16 & 14.5 \\
\hline $1000 \mathrm{mg} / \mathrm{kgBW}$ of LHE + CYP & 9 & 7 & 9 & 12 & 9.25 \\
\hline
\end{tabular}

Table 3. The antigenotoxic effect as the parameter of PCE/PCE+NCE ratio per 2000 cells

\begin{tabular}{|c|c|c|c|c|c|}
\hline \multirow[b]{2}{*}{ Groups } & \multicolumn{5}{|c|}{ PCE / PCE+NCE (2000 cells) } \\
\hline & $\begin{array}{c}\text { Replication } \\
\text {, }\end{array}$ & $\begin{array}{c}\text { Replication } \\
2\end{array}$ & $\begin{array}{c}\text { Replication } \\
\mathbf{3}\end{array}$ & $\begin{array}{c}\text { Replication } \\
4\end{array}$ & Average \\
\hline Negative control & 52 & 46 & 52 & 46 & 49 \\
\hline CYP control & 24 & 20 & 23 & 21 & 22 \\
\hline $\begin{array}{l}1000 \mathrm{mg} / \mathrm{kgBW} \text { of } \mathrm{LHE} \\
\text { control }\end{array}$ & 53 & 49 & 55 & 52 & 52.25 \\
\hline Solvent control & 54 & 44 & 50 & 46 & 48.5 \\
\hline $250 \mathrm{mg} / \mathrm{kgBW}$ of LHE + CYP & 35 & 38 & 35 & 25 & 33.25 \\
\hline $500 \mathrm{mg} / \mathrm{kgBW}$ of LHE + CYP & 39 & 43 & 37 & 30 & 37.25 \\
\hline $\begin{array}{l}1000 \mathrm{mg} / \mathrm{kgBW} \text { of } \mathrm{LHE}+ \\
\text { CYP }\end{array}$ & 47 & 46 & 51 & 45 & 47.25 \\
\hline
\end{tabular}

The result of MNCEP, PCE, and NCE were observed by Light microscope with 1000 times magnification. The morphology of that kind of cells were shown in Fig. 1.

\section{CONCLUSION}

The effect of LHE showed in the inhibition of genetic damage in the erythropoietic system induced by cyclophosphamide. The treatment of LHE could increase the $\mathrm{PCE} / \mathrm{PCE}+\mathrm{NCE}$ ratio per 2000 cells compared to the cyclophosphamide control group, so leunca does not cause DNA toxicity.

The treatment of LHE did not cause lethal effect on animal model up to doses of $5000 \mathrm{mg} / \mathrm{BW}$. However, toxicity signs were found in animal model on day 0-6 of the observation. 


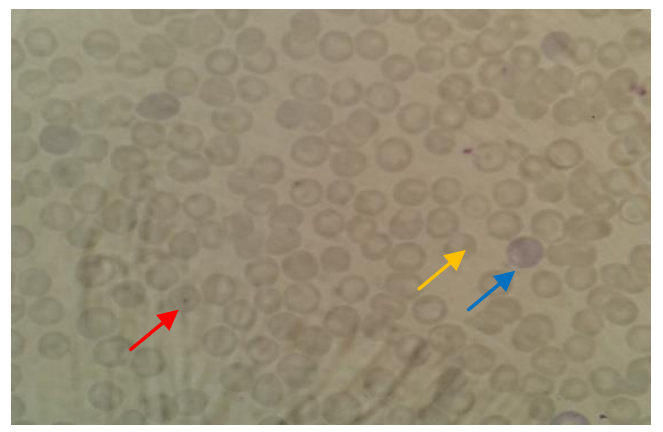

Figure I . MNPCE, PCE, and NCE appearance in blood semar preparat of animal treatment group. The red arrow ( $\longrightarrow$ ) showed the MNPCE, the young erythrocyte contains micronucleus and stained purple with dot. The blue arrow $(\longrightarrow$ ) showed PCE, the young erythrocyte without micronucleus and stained purple without dot. The yellow arrow ( $\longrightarrow$ ) showed NCE, the mature erythrocyte without nucleus and was not stained purple.

\section{REFERENCES}

Anderson, D.I., Bishop, J.B., Garner, R.C., Ostrosky-Wegman, P. and Selby, P.B., 1995, Cyclophosphamide: Review of Its Mutagenicity for An Assessment of Potential Germ Cell Risks, Mutat. Res., 330(I-2), II5-18.

Anindyajati, Sarmoko, Putri, D.D.P., Hermawan, A. and Meiyanto, E., 2010, Combination of Solanum nigrum L. Herb Ethanolic Extract and Doxorubicin Performs Sinergicity on T47D Breast Cancer Cell Line, Indones. J. Cancer Chemoprevent., I (2), 78-84.

Balazs, T., 1970, Measurment of Acute Toxicity. In: Paget G.E, editor, Methods in Toxicology, Oxford and Edinburgh: Blackwell Scientific Publication, pp. 49-8I.

Istiaji, R.P., Fitria, M., Larasati, Tjondro, F., Maruti, A.A., Setyowati, E.P., et al., 2010,
Leunca (Solanum nigrum L.) Herbs Ethanolic Extract Increase Cytotoxic Activity of Cisplatin on Hela Cervical Cancer Cells, Indones. J. Cancer Chemoprevent., I(I), 32-37.

Ji, Y.B., Gao S.Y., ji, C.F. and Zou X., 2008, Induction of Apoptosis in HepG2 Cells by Solanine and $\mathrm{Bcl}-2$ Protein, J. Ethnopharmacol., I I 5(2), 194-202.

Krishna, G. and Hayashi, M., 2000, In vivo Rodent Micronucleus Assay: Protocol, Conduct and Data Interpretation, Mutat. Res., 455(I-2), I55-66.

Pines, J., 1997, Mammalian Cell Cycle, Oncogenes and Tumor Suppressors, New York: IRL Press, Oxford University Press, New York.

Walum, E., 1998, Acute Oral Toxicity, Environ. Health Perspect., I06(Suppl 2), 497503. 